\title{
Effects of atmospheric and climate change at the timberline of the Central European Alps
}

\author{
Gerhard WIESER $^{1 *}$, Rainer MATYSSEK ${ }^{2}$, Roland LUZIAN $^{1}$, Peter ZWERGER $^{1}$, Peter PINDUR $^{3}$, \\ Walter OBERHUBER ${ }^{4}$, Andreas GRUBER ${ }^{4}$ \\ ${ }^{1}$ Dept. Alpine Timberline Ecophysiology, Federal Research and Training Centre for Forests, Natural Hazards and Landscape, \\ Rennweg 1, 6020 Innsbruck, Austria \\ ${ }^{2}$ Dept. of Ecology/Ecophysiology of Plants, Technische Universität München/Weihenstephan, Am Hochanger 13, 85354 Freising, Germany \\ ${ }^{3}$ Institut für Stadt- und Regionalforschung, Österreichische Akademie der Wissenschaften, Postgasse 7, 1010 Wien, Austria \\ ${ }^{4}$ Institute of Botany, University of Innsbruck, Sternwartestraße 15, 6020 Innsbruck, Austria
}

Keywords:

Alpine timberline /

treeline /

global warming /

$\mathrm{CO}_{2} /$

ozone /

water balance /

carbon gain

(Received 21 July 2008; accepted 19 December 2008)

\author{
Mots-clés : \\ limite supérieure alpine de la forêt / \\ limite de croissance des arbres / \\ réchauffement global / \\ $\mathrm{CO}_{2} /$ \\ ozone / \\ bilan hydrique / \\ gain de carbone
}

\begin{abstract}
- This review considers potential effects of atmospheric change and climate warming within the timberline ecotone of the Central European Alps. After focusing on the impacts of ozone $\left(\mathrm{O}_{3}\right)$ and rising atmospheric $\mathrm{CO}_{2}$ concentration, effects of climate warming on the carbon and water balance of timberline trees and forests will be outlined towards conclusions about changes in tree growth and treeline dynamics.

- Presently, ambient ground-level $\mathrm{O}_{3}$ concentrations do not exert crucial stress on adult conifers at the timberline of the Central European Alps. In response to elevated atmospheric $\mathrm{CO}_{2}$ Larix decidua showed growth increase, whereas no such response was found in Pinus uncinata. Overall climate warming appears as the factor responsible for the observed growth stimulation of timberline trees.

- Increased seedling re-establishment in the Central European Alps however, resulted from invasion into potential habitats rather than upward migration due to climate change, although seedlings will only reach tree size upon successful coupling with the atmosphere and thus loosing the beneficial microclimate of low stature vegetation.

- In conclusion, future climate extremes are more likely than the gradual temperature increase to control treeline dynamics in the Central European Alps.
\end{abstract}

Résumé - Effets des changements atmosphériques et des changements climatiques à la limite supérieure de la forêt en Europe dans les Alpes centrales.

- Cette étude examine les effets potentiels des changements atmosphériques et du réchauffement climatique au sein de l'écotone que constitue la limite supérieure de la forêt dans les Alpes centrales en Europe. Après avoir mis l'accent sur les effets de l'ozone $\left(\mathrm{O}_{3}\right)$ et de l'augmentation des concentrations atmosphériques du $\mathrm{CO}_{2}$, les effets du réchauffement climatique sur le bilan de carbone et le bilan hydrique des arbres et des forêts à la limite supérieure de la forêt seront présentés en vue de tirer des conclusions sur l'évolution de la croissance des arbres et sur les dynamiques de la limite supérieure de la forêt.

- Actuellement, les concentrations en $\mathrm{O}_{3}$ de l'air ambiant au niveau du sol n'exercent pas un stress critique sur les arbres adultes à la limite supérieure de la forêt dans les Alpes centrales en Europe. En réponse à des concentrations élevées en $\mathrm{CO}_{2}$ Larix decidua a montré une augmentation de la croissance, alors qu'une telle réponse n'a pas été trouvée chez Pinus uncinata. Globalement, le réchauffement climatique apparaît être le facteur responsable de la stimulation de la croissance observée chez les arbres à la limite supérieure de la forêt.

- Toutefois, l'augmentation de la réinstallation des semis dans les Alpes centrales en Europe est le résultats de l'invasion d'habitats potentiels plutôt qu'une migration en altitude due aux changements climatiques, bien que les semis atteindront seulement la taille des arbres après un couplage réussit avec l'atmosphère et donc perdant le microclimat favorable d'une végétation basse.

- En conclusion, les phénomènes climatiques extrêmes futurs sont plus susceptibles de contrôler les dynamiques de limite supérieure de la forêt, que l'augmentation progressive de la température dans les Alpes centrales en Europe.

\footnotetext{
*Corresponding author: Gerhard.Wieser@uibk.ac.at
} 


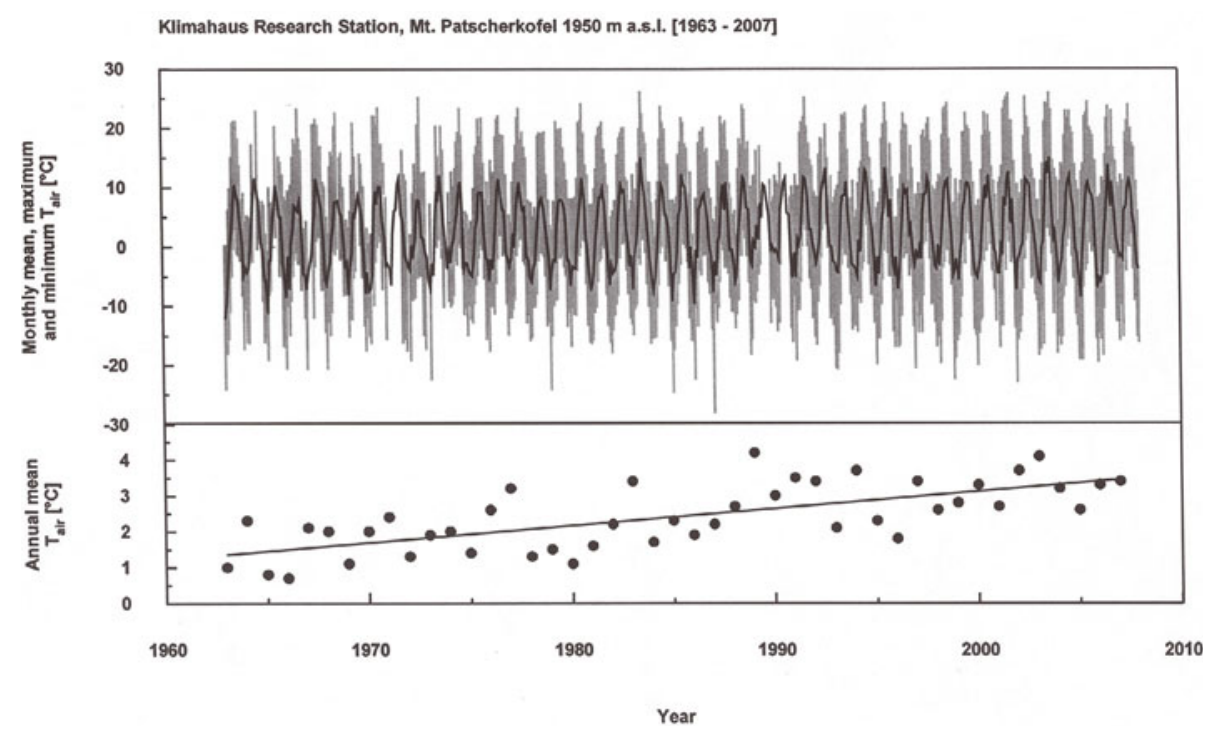

Figure 1. Top: Monthly average (solid line), maximum and minimum (grey bars) air temperature from January 1963 throughout December 2007 and (bottom) mean annual air temperature at the Mt. Patscherkofel Klimahaus Research Station, Austria, 1950 m a.s.1.

\section{INTRODUCTION}

The alpine timberline designates the limit of forest growth as imposed by the environmental specificities of this ecotone. Rather than being an abrupt boundary, this timberline typically forms a transition zone between the forest line (i.e. the upper limit of closed-canopy conditions) and the tree line (disappearance of life form tree) mediating to the krummholz zone above (Däniker, 1923; Holtmeier, 2003; Slatyer and Noble, 1992; Tranquillini, 1979; Wardle, 1974; Wieser and Tausz, 2007). The tree limit is defined by tree heights of 2 to $3 \mathrm{~m}$ (Körner, 2007; Wieser and Tausz, 2007), which ensure tree crowns to be well coupled with the atmosphere (also in winter, as protruding above the snow cover). Above the tree line, tree and shrub species are deformed to krummholz, characterized by stunted habit, either hugging the ground or attaining, at most, the height of the snow cover (Tranquillini, 1976). Hence, such plants experience microclimates similar to dwarf plants which dominate the alpine zone at the next higher vegetation belt (Grace et al., 2002).

Although at a given site the position of the timberline depends on a multitude of factors, in particular, temperaturecaused limitations in growth (Körner, 1998), such restrictions are interrelated with incomplete tissue maturation, sometimes inadequate resistance to climatic stress, which altogether determines the altitudinal distribution limit of trees (Wieser and Tausz, 2007). A number of hypotheses have been posed to functionally explain the occurrence of timberlines (Körner, 2003). The multi-factorial interactions govern the transition from the life form tree to low-stature vegetation such as dwarfshrubs and alpine grasslands.

Awareness currently increases about timberline-associated forest ecosystems because these are expected to undergo significant alterations due to climate warming and changes in the chemical composition of the lower atmosphere (Grace et al.,
2002; Holtmeier and Broll, 2007; Walther et al., 2005, Wieser and Tausz, 2007). Taking into account that growth and regeneration of trees within the timberline ecotone is mainly controlled by temperature (Körner, 2003), global warming is supposed to cause both an upward advancement of trees beyond the present tree limit (Walther, 2003) and denser forests below the forest limit (Grace et al., 2002). Such changes may have important implications on biogeochemical cycles and probably also on biodiversity within the timberline ecotone as ample evidence exists about climate warming by about $0.6^{\circ} \mathrm{C}$ during the last century (Jones et al., 1998). Global change models predict even further temperature increase by 1.4 to $5.8{ }^{\circ} \mathrm{C}$ during the upcoming decades (IPCC, 2007). Such changes may be most pronounced in the European Alps (Beniston et al., 1997; Diaz and Bradley, 1997). Data from the timberline ecotone in the Central Austrian Alps show that during the last decade mean annual air temperature was higher, on average, by $1{ }^{\circ} \mathrm{C}$ as compared to the period before (Fig. 1) and changes appear to be greatest during spring $\left(+1.4{ }^{\circ} \mathrm{C}\right)$ and summer $\left(+1.6^{\circ} \mathrm{C}\right)$ as compared to fall $\left(0{ }^{\circ} \mathrm{C}\right)$ and winter $\left(+0.6{ }^{\circ} \mathrm{C}\right)$. The overall warming is associated with changes in snow cover volume and duration (Hantel et al., 2000; Beniston et al., 2003). Due to increasing surface and air temperatures especially in spring (Groisman et al., 1994), the length of the growing season has markedly increased during recent years (Beniston et al., 2003; Hantel et al., 2000; Menzel and Fabian, 1999). In addition, winter rains will probably increase, whereas precipitation deficits may occur during the later part of the growing season (Breda et al., 2006; Brunetti et al., 2006). Moreover, other factors of climate change such as enhancements in atmospheric $\mathrm{CO}_{2}$ concentration as well as tropospheric ozone may interact in concert with climate warming.

In addition, for millennia humans have influenced the timberline ecotone (Patzelt, 1995) as accessible slopes of moderate inclination were often deforested to gain seasonally used 
pasture land (Holtmeier, 1973; Leidlmair, 1983). As a consequence, this impact has significantly lowered the natural treeline by 150 to $300 \mathrm{~m}$ to below the postglacial potential climatic treeline (Holtmeier 1986, 1994). For that reason, it is uncertain whether the present actual timberline in the European Alps reflects equilibrium between climate and tree internal eco-physiological factors.

This paper summarizes the present knowledge about climate change at the timberline ecotone. Focus will be on the Central European Alps, as geographical variation in mesoclimate and interference by Mediterranean, oceanic and continental influences (Beniston et al., 1977) hinder to draw a unique scenario for the whole European Alps (cf. also Theurillat and Guisan, 2001). After examining the impact of an altered atmospheric chemistry on the physiological behaviour of timberline trees, we will address possible effects of climate warming on tree carbon gain with respect to foliage type (deciduous vs. evergreen). Consequences for net primary production, growth, and water balance will be discussed, emphasizing potential effects of climate warming and land use change on the upward migration of trees and forest expansion.

\section{ALTERED ATMOSPHERIC CHEMISTRY}

\subsection{Effects of ozone}

During the last century the chemical composition of the lower troposphere has drastically changed over Europe. Ground-level ozone $\left(\mathrm{O}_{3}\right)$ concentrations have at least doubled and annual means nowadays range between 40 and $50 \mathrm{~nL} \mathrm{~L}^{-1}$ (Stockwell et al., 1997). High-altitude forests generally experience higher $\mathrm{O}_{3}$ levels (less $\mathrm{O}_{3}$ destruction through $\mathrm{NO}_{x}$, stratospheric $\mathrm{O}_{3}$ intrusions, less re-circulation of polluted air masses) than forests at low elevation (Smidt, 1993; Herman et al., 2001) so that also $\mathrm{O}_{3}$ uptake rates of trees are higher (Wieser et al., 2000). Nevertheless, there is no indication at present that ground level $\mathrm{O}_{3}$ affects the net carbon gain of timberline trees (Häsler et al., 1991; Matyssek et al., 1997). $\mathrm{O}_{3}$ fumigation experiments conducted at the forest limit in the central Austrian Alps showed that long lasting mean $\mathrm{O}_{3}$ concentrations lower than $100 \mathrm{~nL} \mathrm{~L}^{-1}$ did not significantly affect the carbon gain adult Picea abies, Pinus cembra, and Larix decidua trees after exposure throughout one growing season (Havranek et al., 1989; Wieser and Havranek, 2001; Volgger, 1995; Wieser et al., 2006). This is attributable to the detoxification capacity of oxygen radicals which is greater in timberline than lowland trees (Hecke et al., 2003; Polle and Rennenberg, 1992; Polle et al., 1992; Tausz et al., 1998) because high altitude plants are generally exposed to higher oxidative stress due to lower temperature, higher irradiance and higher $\mathrm{O}_{3}$ concentration. Apoplastic ascorbate concentration in spruce needles was shown to be 25 to $75 \%$ higher at timberline than at elevations below $1000 \mathrm{~m}$ a.s.l. (Polle et al., 1995). Moreover, conifers at the timberline possess lower specific leaf area (SLA, leaf area per unit dry mass; Benecke et al., 1981; Hurtin and Marshall, 2000; Richardson et al., 2001; Wieser and Tauz, 2007). High antioxidant levels at low SLA are apparently conducive to low $\mathrm{O}_{3}$ sensitivity as observed in timberline provenances of Picea abies (Havranek et al., 1990) and Larix decidua (Volgger, 1995), as $\mathrm{O}_{3}$ susceptibility positively correlates with SLA in parallel with decreasing antioxidant levels (cf. Matyssek et al., 2008a). Such findings indicate the ambient ground-level $\mathrm{O}_{3}$ concentration per se to not exert crucial stress on timberline trees of the Central European Alps (Matyssek et al., 1997). In the absence of evident $\mathrm{O}_{3}$ injury on timberline trees in the Central Austrian Alps (Matyssek et al., 1997), one-year-old needles of Pinus cembra trees in declining stands in the southern (more maritime) French Alps showed symptoms of yellowing and defoliation (Bianco and Dalstein, 1999; Dalstein et al., 2002) which were attributable to $\mathrm{O}_{3}$ impact (Vollenweider et al., 2003). Thus, the action of $\mathrm{O}_{3}$ must be evaluated in concert with other environmental factors which altogether determine the tree's sensitivity to $\mathrm{O}_{3}$.

\subsection{Effects of elevated $\mathrm{CO}_{2}$}

The rise in atmospheric $\mathrm{CO}_{2}$ concentration, having reached approximately $380 \mu \mathrm{L} \mathrm{L}^{-1}$ at present, at a current rate of 1-2 $\mu \mathrm{L} \mathrm{L}^{-1}$ year $^{-1}$, is another global phenomenon (Keeling et al., 1995; Keeling and Whorf, 2005). Three years of freeair $\mathrm{CO}_{2}$ enrichment at the timberline in Switzerland proved light-saturated net photosynthesis of 30-year-old Larix decidua and Pinus uncinata trees to be significantly higher under elevated $\mathrm{CO}_{2}$ than of control trees under ambient $\mathrm{CO}_{2}$ concentration (Handa et al., 2005; Hättenschwiler et al., 2002). Non-structural carbohydrates were also increased under elevated $\mathrm{CO}_{2}$, suggesting that it is not carbon gain that presently limits tree growth at the timberline but the rate at which glucose can be utilized (Grace et al., 2002). As this latter rate is temperature-driven, low temperature rather than $\mathrm{CO}_{2}$ supply was acknowledged to limit tree growth at high altitude (Körner, 2003). Hence, warming rather than elevated $\mathrm{CO}_{2}$ is likely to shift the timberline towards higher elevation as compared with the current situation (see below).

Nevertheless, $\mathrm{CO}_{2}$ enhancement caused a significant stimulation in lateral shoot growth and a cumulative four-year response of $41 \%$ in radial stem increment of deciduous Larix decidua whereas no such response was observed in evergreen Pinus uncinata (Handa et al., 2005, 2006). The difference in branch growth perhaps relates to the contrasting leaf habits of these two tree species (Cornelissen et al., 1999). Furthermore, if the observed growth response to elevated $\mathrm{CO}_{2}$ depends on foliage type it is likely that other factors such as temperature and hence the length of the growing season might also be involved in the observed growth stimulation of deciduous larch as compared to evergreen pine (cf. also Crawford, 2008). One needs to caution, however, that even three years of experimental $\mathrm{CO}_{2}$ enhancement (Handa et al., 2005; Hättenschwiler et al., 2002) might be too limited at the timberline, characterised by short growing seasons that alternate with prolonged winter dormancy, to conclude about long-term responses (cf. Norby et al., 1999; Saxe et al., 1998). Evidence exist that $\mathrm{CO}_{2}$ effects will decline over time due to metabolic acclimation 


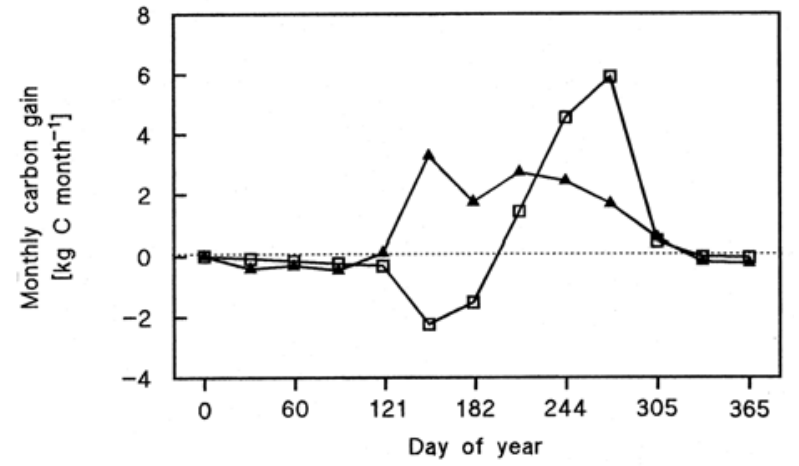

Figure 2. The seasonal course of the monthly carbon balance of a 95-

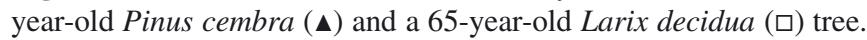
Measurements were made at Mt. Patscherkofel (Klimahaus) Austria $1950 \mathrm{~m}$ a.s.1. (Modified after data from Wieser et al., 2005 and Havranek and Matyssek, 2005).

and age-related stand dynamics in competition for above and belowground resources (Hättenschwiler et al., 1997). Körner et al. (2005) also failed to find stimulation in growth and litter production after four years of $\mathrm{CO}_{2}$ enrichment in mature temperate forest trees. In general, tree growth tends to acclimate to enhanced $\mathrm{CO}_{2}$ supply upon long-term exposure, sustaining growth rates similar to those under the current, ambient $\mathrm{CO}_{2}$ levels (Körner, 2006). This latter phenomenon supports the conclusion that tree growth is carbon-saturated already under the present environmental conditions (Körner, 2003). Timberline trees do not appear to be an exception, as their tissues are highly charged with photosynthates (Hoch and Körner, 2003; Hoch et al., 2002; 2003).

\section{POTENTIAL IMPACTS OF CLIMATE WARMING}

\subsection{Effects on the carbon balance}

The carbon balance is determined by the carbon uptake of the foliage and the carbon released via respiratory processes. The crucial factor for carbon fixation is the time span which enables a positive daily carbon balance. This time span is defined by the phenological dependence of ecophysiological processes. For example, Larix decidua does not unfold new needles before mid-June, whereas $P$. cembra achieves its maximum monthly carbon gain during the early growing season (Fig. 2). In addition, larch needles turn yellow in early October, whereas net photosynthesis in P. cembra ceases approximately one month later. Hence, the seasonal photosynthetic period of larch is 130 days on average as compared to approximately 180 days in P. cembra (Friedel, 1967; Havranek and Tranquillini, 1995). The shorter photosynthetic period in the deciduous $L$. decidua as compared to the evergreen $P$. cembra (Fig. 2) is however, compensated by a higher photosynthetic capacity and a higher daily and seasonal carbon gain (Tranquillini, 1962). Nevertheless, the carbon-use efficiency (i.e. ratio of gross photosynthesis vs. respiration; sensu Larcher, 2001) did not differ significantly and approached 7.0

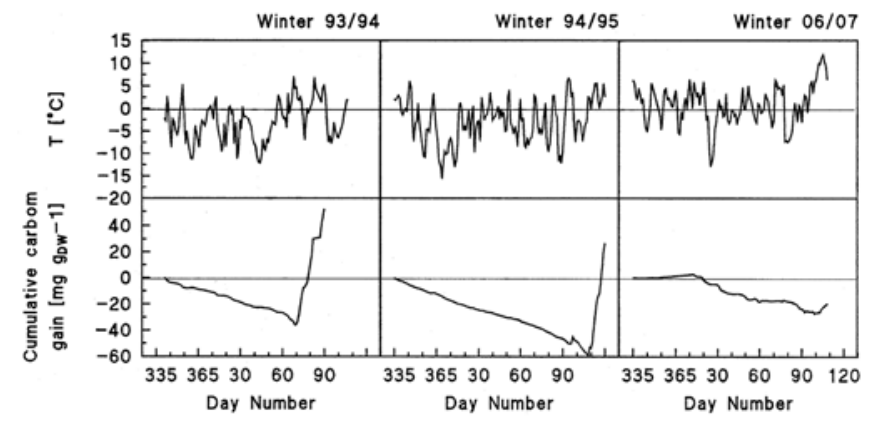

Figure 3. Seasonal patterns of daily mean air temperature (top) and cumulative carbon gain (bottom) of current to two-year-old needles of Pinus cembra at the timberline during winter (December, January, February) and early spring (March, April) of three years contrasting with respect to temperature. (Combined after data from Wieser, 1997 and Gruber et al., unpublished).

and 7.6 in L. decidua and P. cembra, respectively (Wieser and Tausz, 2007).

Since the growing season at the timberline is very short, small temperature differences at the beginning and the end of the snow-free period can have large effects on the annual carbon gain of evergreen conifers (Fig. 3). In general, the daily carbon balance of Pinus cembra needles is negative from December throughout March (Fig. 3; winter 1994-1995). During long-lasting warm periods in late winter, however, metabolic activity may increase (Fig. 3; winter 1993-1994) and daily carbon gain can reach up to $30 \%$ of summer levels. The winter of 2006-2007 was extraordinarily warm (average winter temperature Dec.-Feb. $-1.1^{\circ} \mathrm{C}$ ) as compared to the 40 -year average of $-4.0^{\circ} \mathrm{C}$, and hence, significantly raised the carbon balance during the cold season (Fig. 3; winter 2006-2007). Moreover, Kronfuss and Havranek (1999) showed growth of Pinus cembra in a subalpine afforestation to be positively related to the length of the growing season.

Low temperature during winter dormancy by contrast hardly affects the annual carbon gain of conifers (Havranek and Tranquillini, 1995; Tranquillni, 1959a; 1959b; Wieser, 1997; Wieser and Bahn, 2004) and the overall carbon balance of timberline forests (Wieser and Stöhr, 2005). Relationships between gross primary production (GPP) and ecosystem respiration (ER) show under current climatic conditions in a Pinus cembra timberline forest of the Austrian Alps warm temperature during the growing season and their effects on ER to be key factors that limit net ecosystem production (Fig. 4; Wieser and Stöhr, 2005). Modelling suggests increase in mean annual temperature by $1.0^{\circ} \mathrm{C}$ and its effect on growing season length to raise GPP and ER of this forest by about 15 and $10 \%$, respectively, causing net ecosystem production to be enhanced by $5 \%$ relative to the present situation. Measurements in a boreal Scots pine forest in eastern Finland support this calculation (Zha et al., 2004), and warmer climatic conditions in future are expected to favour GPP more than ER (Grace and Rayment, 2000). Such a scenario may increase the carbon sequestration of timberline forest ecosystems (Bergh and Linder, 1999). 


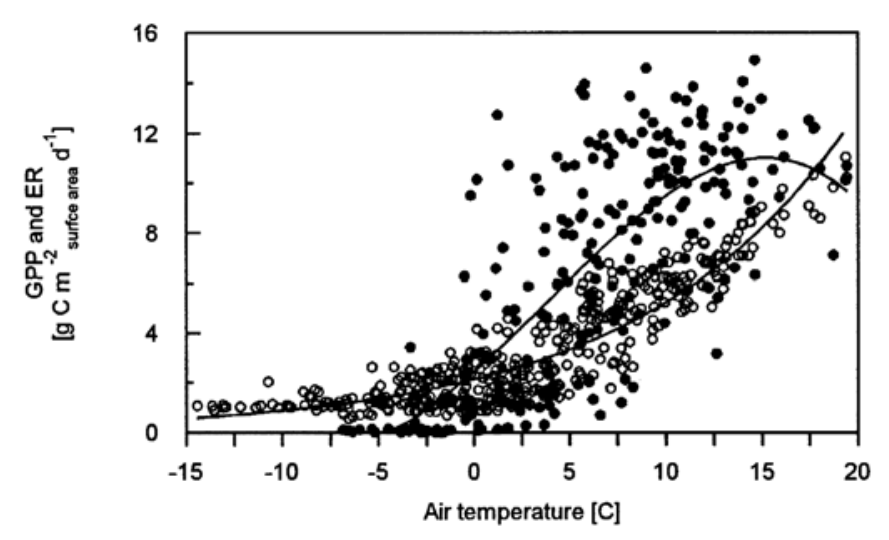

Figure 4. Temperature dependence of gross primary production (GPP; closed symbols) during the growing season and of ecosystem respiration (ER; open symbols) during an entire annual course in a 95-year-old Pinus cembra forest at Mt. Patscherkofel (Klimahaus), Austria, 1950m a.s.1. (Modified after data from Wieser and Stöhr, 2005).

Climate warming is also associated with changes in snow cover volume and duration (Beniston et al., 2003; Hantel et al., 2000) and precipitation patterns (Brunetti et al., 2006). Due to increasing surface and air temperatures, especially in spring (Groisman et al., 1994) the length of the growing season has markedly increased during recent years (Beniston et al. 2003; Hantel et al., 2000; Menzel and Fabian, 1999). For example, although not statistically significant, the growing season at the timberline of the central Austrian Alps amounted to $168 \pm 12$ days during the period of 1972 through 1985 , and to $196 \pm 23$ days during 1994 through 2004 (Wieser and Tausz, 2007). Thus, with respect to carbon gain evergreen conifers at the timberline may benefit from future climate warming as compared to deciduous trees, when retaining their photoperiod (Larcher, 1994). Nevertheless, timing of budburst is a significant phenological event often involving high temperature for breaking winter dormancy in spring. Conversely, warm winters will increase the frequency of wet snow events, winter thaw and even snow-free periods, which will probably increase the number of freeze-thaw-cycles (Mayr et al., 2003) and, hence, the risk of embolisms in the xylem water (Mayr et al., 2007). Further risks for tree survival within the timberline ecotone may arise from early frost dehardening in spring upon warmer winter temperatures (Neuner, 2007) as well as frost drought (Oberhuber, 2004; Tranquillini, 1976). The latter is assumed to be one of the main causes for the upper limit of tree growth in high mountains outside the tropics (Baig and Tranquillini, 1980; Christersson et al., 1988; Schwarz, 1983; Sowell et al., 1982; Tranquillini, 1976; 1979; Turner, 1968) because of insufficient maturation of cuticles and buds during the preceding summer (Hadley and Smith, 1989; Holtmeier, 1974). Winter desiccation can occur throughout late winter and early spring when water losses by cuticular transpiration cannot be compensated due to frozen soil and limited water reserves in the above ground tissues (Hadley and Smith, 1990; Havranek and Tranquillini, 1995; Larcher, 1957; 1963;
1985; Michaelis, 1934a; 1934b; Sakai and Larcher, 1987; Tranquillini, 1976; 1979; 1982).

\subsection{Effects on the water relations}

Ample precipitation and moderate evaporative demand in general cause soil water content to be sufficiently high to meet the trees' water demand in high-elevation forests of the European Alps. As a consequence, timberline trees are rarely forced to restrict transpiration (Matyssek et al., 2008b; Tranquillini, 1979). In general, soil moisture at the timberline of the Central European Alps seldom drops below 20\% vol. (Guggenberger, 1980; Gunsch, 1972; Neuwinger, 1970, 1980; Neuwinger-Raschendorfer, 1961; Wieser, 2004). Nevertheless, soil water availability can differ by micro-scale variation in soil depth and soil type so that soil water potential may locally be as low as -1 MPa (Anfodillo et al., 1998). Such low levels, however, are not critical for trees as they stay significantly above the vulnerability threshold of cavitation (Breda et al., 2006) through stomatal closure (Havranek and Benecke, 1978). Under ample soil water availability of a future warmer climate the water uptake capacity will possibly be improved through growth stimulation of the mycorrhizal root system and enlargement of its absorbing surface. In addition, water uptake may also be enhanced by rising soil temperature through lowered water viscosity (Kaufmann, 1975) and increased permeability of root membranes (Goldstein et al., 1985; Wan et al., 1999).

Conversely, limited soil water availability at sites with a shallow soil layer and increased evaporative demand upon climate warming may endanger trees through water imbalances, in particular, at their upper distribution limit where growth habit becomes stunted and deformed towards the krummholz zone (Holtmeier, 2003; Tranquillini, 1979; Wieser and Tausz, 2007). This latter zone already today is affected by temporary soil drought especially at wind exposed ridges and leeward sun-exposed slopes with thin soil layer (Aulitzky, 1963; 1984).

\subsection{Effects on tree growth}

Studies in the timberline ecotone of Central European Alps show increase in tree-ring widths after the so-called "little ice age" (1560 through 1870; Carrer and Urbinati, 2006; Paulsen et al., 2002; Rolland et al., 1998). Carrer and Urbinati (2006) proposed June temperature and precipitation to drive radial growth of Larix decidua in the Eastern Italian Alps during the last 200 y. Nicolussi et al. (1995) assumed atmospheric $\mathrm{CO}_{2}$ enrichment to have stimulated tree-ring width of Pinus cembra in the central Austrian Alps during the second half of the $19^{\text {th }}$ century. However, $\mathrm{CO}_{2}$ enhancement was minor at that time. Furthermore, timberline trees are unlikely to be limited in their carbon balance, but they are by low temperature (see above; Körner, 1998, 2003). In addition to temperature, nitrogen deposition may be considered as a growth stimulator. However, time series analysis does not unveil positive correlation between annual ring width in the timberline ecotone of the 


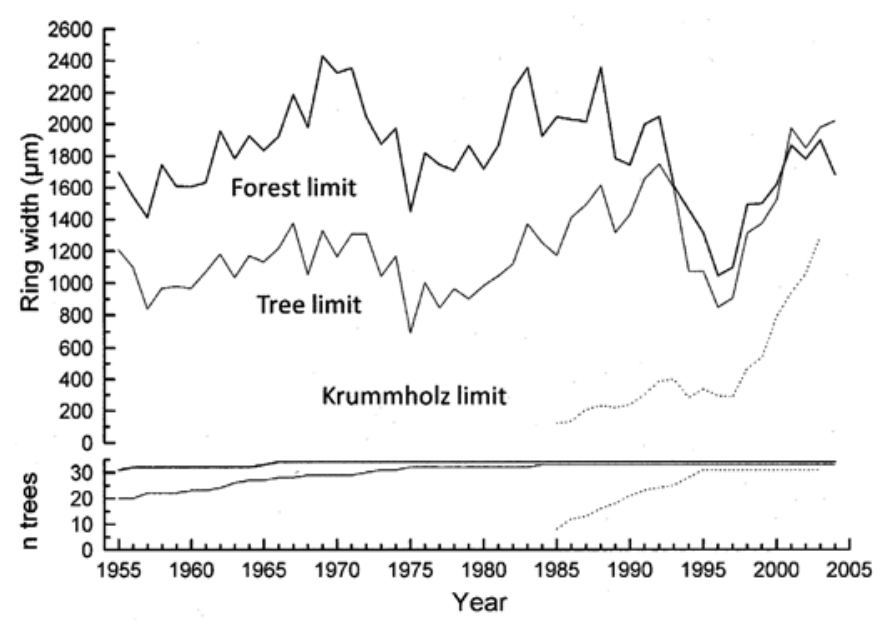

Figure 5. Radial stem growth of Pinus cembra from the forest limit (1950 $\mathrm{m}$ a.s.1.), the tree limit (2110 $\mathrm{m}$ a.s.1.) and the krummholzlimit (2180 $\mathrm{m}$ a.s.1.) on Mt. Patscherkofel during the period 19552004. Annual increments were measured on increment cores (2 radii per tree) taken at 1.3 and $1 \mathrm{~m}$ stem height (forest and tree limit, respectively) and on stem discs cut directly above soil surface at the krummholz-limit (stem height $<50 \mathrm{~cm}$ ) (Selva and Oberhuber, unpublished).

Austrian and Swiss Alps (Nicolussi et al., 1995; Paulsen et al., 2000) and nitrogen deposition (Psenner and Nickus, 1986).

Most recently, dendroclimatological studies conducted within the timberline ecotone of the Central European Alps have shown, however, that radial stem growth is limited by low summer temperature (Büntgen, 2005; Carrer and Urbinati, 2004; Frank and Esper, 2005; Oberhuber, 2004). Still, variation between summer temperature and annual ring increment of Picea abies and Larix decidua was reported by Carrer and Urbinati (2006) and Büntgen et al. (2006). The latter authors related this variation in Picea abies to temperature-induced increase in late-summer drought that coincided with the recent trend of warming. Spatial variability in radial growth reductions of Pinus cembra at the timberline was also related in the 1990s to the occurrence of temporary, temperature-induced drought during the growing season (Oberhuber, 2004). Moderate increases in annual increments of Pinus cembra within the timberline ecotone of Mt. Patscherkofel (Tyrol, Austria) under the heat-wave of 2003 (Beniston, 2004; Schär et al., 2004), when mean summer temperatures exceeded the longterm mean of $1967-2002$ by c. $4.1^{\circ} \mathrm{C}$ and precipitation was reduced by $24 \%$, might be explained accordingly (Fig. 5 ; cf. also Oberhuber et al., 2008). These interpretations are consistent with results of Anfodillo et al. (1998), who found that soils at the timberline became physiologically dry during the growing season, and high evaporative demand negatively affected the radial stem growth of Pinus cembra. Conversely, missing adequate growth response to recent climate warming may suggest the presence of temperature thresholds (Wilmking et al., 2004) and/or compensatory effects of climatic factors (Oberhuber et al., 2008; Pfeifer et al., 2005).
Besides air temperatures, soil temperature and associated root metabolism determine tree growth (Körner and Hoch, 2006). Low soil temperature as nowadays prevailing at the timberline are known to limit root growth (Häsler et al., 1999; Oberhuber, 2007; Tranquillini, 1973; Turner and Streule, 1983) and soil temperatures below $6{ }^{\circ} \mathrm{C}$ cause critical inhibition (Alvarez-Uria and Körner, 2007). This is meaningful to timberline trees with extensively mycorrhizal fine roots, as mycorrhization appears to be a pre-requisite of tree growth and survival at high altitude (Haselwandter, 2007; Moser, 1967).

Soil temperature influences above-ground metabolism and growth. In the timberline ecotone near Obergurgl, Austria (2070 m a.s.1.), Havranek (1972) found a linear correlation in situ between daily carbon gains of Pinus cembra seedlings and daily mean soil temperature at $10 \mathrm{~cm}$ depth of 0 to $7{ }^{\circ} \mathrm{C}$ $\left(C_{\text {day }}=7.12 \times T_{\text {soil }}+12.92, r^{2}=0.90\right)$, while higher root zone temperatures do not limit photosynthesis. Moreover, artificial soil cooling reduced the diameter increment of stunted Pinus cembra trees near the krummholz limit at Mt. Patscherkofel, Innsbruck; (Oberhuber et al., unpublished observations). This finding is consistent with those of a soil warming experiment in a boreal spruce stand where stemwood production was significantly increased at elevated soil temperature (Strömgren and Linder, 2002).

\section{TREELINE SHIFTS}

As both growth and reproduction (Smith et al., 2003) of trees are controlled in the timberline ecotone by temperature, an upslope migration of tree species has been predicted under climate change (Grace et al., 2002; Holtmeier and Broll, 2007; Walther, 2003; and further reference therein). In fact, increased seedling establishment beyond the forest limit has been detected in the Swiss (Gehring-Fasel et al., 2007) and the Austrian Alps (Fig. 6; Luzian and Pindur, 2007). Nevertheless, the treeline assumed after the postglacial optimum was considerably lowered by human impacts (pasturing, mining; Holtmeier, 1973; Holtmeier and Broll, 2007; Leidlmair, 1983). Furthermore, recent changes in land-use management are considered to be a driving force for changes in ecosystem functioning and dynamics (Cernusca, 1999). Gellrich et al. (2007) observed a close relationship between land abandonment and forest re-growth in mountainous regions of Switzerland. At the Swiss timberline ecotone Gehring-Fasel et al. (2007) found that a large portion of seedling re-establishment resulted from invasion into potential habitats rather than an upward migration. Hättenschwiler and Körner (1995) and Paulsen et al. (2000) also failed to find evidence for upward migration of pine seedlings in the timberline ecotone of the Swiss Alps. Similar results are also reported from North America (Szeicz and MacDonald, 1995), Canada (Klasner, 2002) and the Ural Mountains in Russia (Shiyatov et al., 2005). Conversely, a recent advancement of the tree limit has been reported from the Swedish Scandes (Kullman, 2002). As such trends are lacking in the Alps (Gehring-Fasel et al., 2007) the treeline in the Central European Alps is said to behave in a "conservative" way (Grace et al., 2002). Tree advancement to higher elevations 


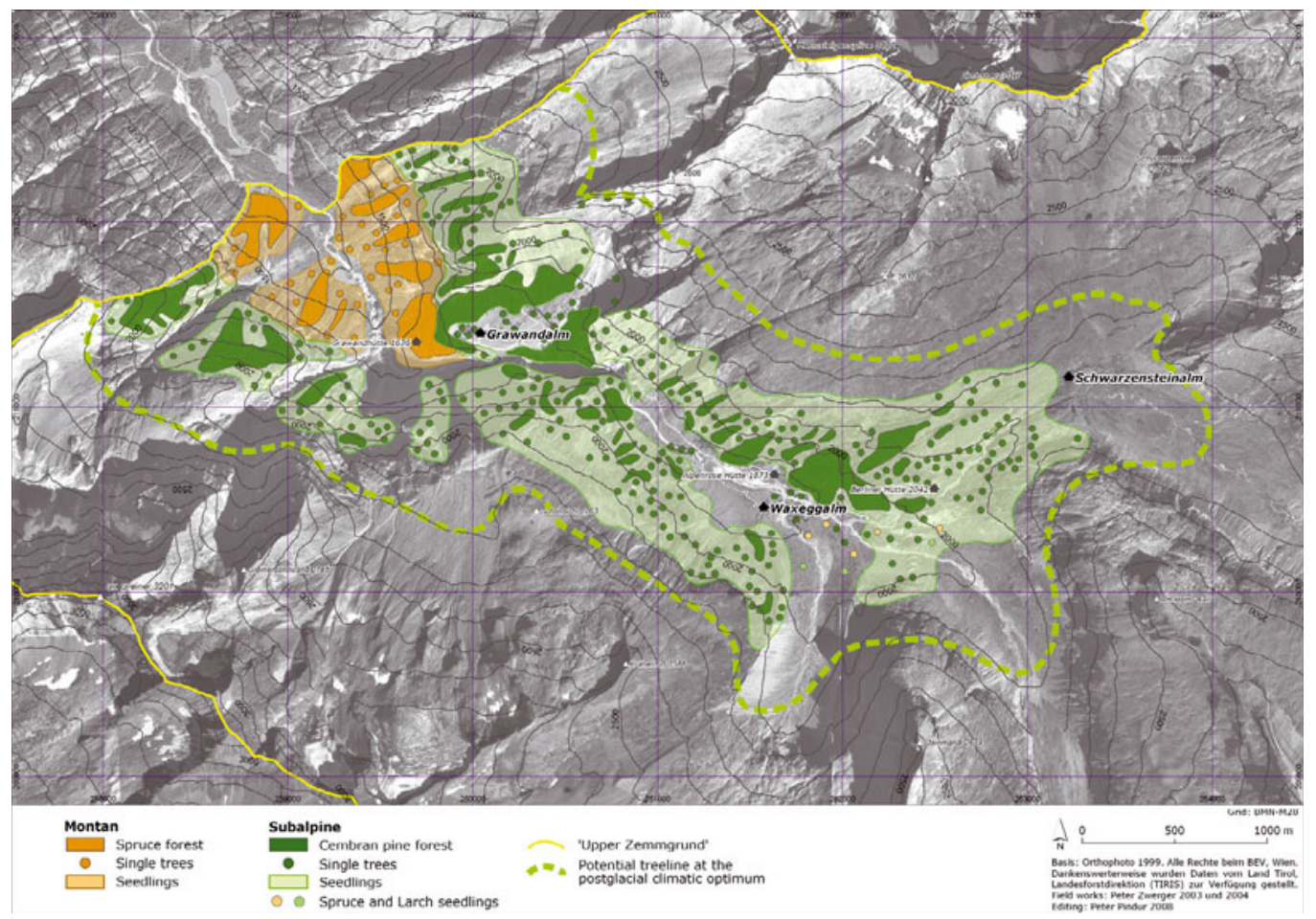

Figure 6. Actual distribution of montane Norway spruce (Picea abies) and subalpine cembran pine (Pinus cembra) forests, single trees, seedling re-establishment in an abandoned alpine pasture, and the reconstructed potential treeline during the postglacial optimum in the Oberer Zemmgrund, Zillertaler Alpen, Austria (modified after Zwerger and Pindur, 2007).

however, also depends on reproduction and survival of the recruitment (Smith et al., 2003). Although the reproduction has been less studied than growth in the given context, it has already been observed by Tranquillini (1979) that production of viable seeds above the forest limit often fails in years with a cool growing season. Warmth is likely to support viable seed production and seedling establishment. Tree advancement to higher elevations is coupled, in addition, with enhanced wind exposure. Hence, frost drought as well as needle abrasions by snow and ice (Holtmeier, 2003) are likely to increase as long as a tree population is too small to enhance snow accumulation (Kronfuss and Havranek, 1999). Thus, seedling establishment and survival will profit from sheltered micro-sites with respect to slope inclination and exposure (Smith et al., 2003). Differences in radiation dose resulting from topographic exposure are reflected in variations of soil and air temperature, snow cover duration, soil moisture, and consequently in the distribution of the vegetation (Aulitzky, 1963, 1984; Kronfuss, 1970; Larcher, 1985; Turner, 1993; Turner et al., 1975). Ingrown or advanced seedlings will only reach tree size when they can survive after being decoupled from the beneficial microclimate of low stature vegetation. Finally, tree development also depends on extreme events such as drought, severe frost during the growing season, frost drought, and even biotic stress by pathogens and herbivores. Thus severe climatic episodes are more likely than mean temperature to control tree population dynamics in timberline ecotone of the Central European Alps in future.

\section{CONCLUSIONS}

Increases in $\mathrm{O}_{3}$ and $\mathrm{CO}_{2}$ levels along with altered temperature and moisture regimes interact in their impact on timberline trees and forests in complex ways. There is no indication at present however, that ground level $\mathrm{O}_{3}$ affects the net carbon gain of timberline trees. This kind of tolerance appears to be based on intrinsic adaptation to oxidative stress which increases with altitude (Wieser et al., 2001) not only because of higher ambient $\mathrm{O}_{3}$ levels than at low elevation, but also due to lower temperature and higher irradiance. Hence, the capacity of detoxifying oxygen radicals is higher in trees at their upper distribution limit as compared to trees at low elevation (Polle et al., 1992; Hecke et al., 2003).

Elevated $\mathrm{CO}_{2}$ hardly affects tree growth (Körner, 2003) as responsiveness depends on foliage type (Handa et al., 2005; 2006) so that low air temperature rather than carbon is the limiting factor of growth in trees at their upper distribution limit (Wieser and Tausz, 2007). With respect to carbon gain, trees and stands of the timberline ecotone will benefit from future climate warming as temperature-driven carbon loss by respiration is likely to be over-compensated by the concurrently increasing gross primary production (GPP; Wieser and Stöhr, 2005). Thus, the additional carbon acquired by timberline trees upon warming, including prolonged growing seasons, is available to various metabolic demands, especially, to match the subtle balance between above (light) and belowground resource sequestration (water, nutrients; Mooney 
and Winner, 1991). In particular, competitiveness for belowground resources is crucial for tree survival at the timberline (Calaway, 1998). Although future warming will improve the water uptake from soils, increasing evaporative demand may perturb the water balance at wind and sun-exposed sites with shallow soils. Such risk is indicated already today at the boundary between tree line and krummholz zone (Aulitzky, 1984).

The ample re-establishment of seedlings currently observable at the timberline of the Central European Alps occurs to a major extent in potential habitats of the respective tree species rather than upon upward-migration (Gehring-Fasel et al., 2007; Zwerger and Pindur, 2007). Invasion into such habitats is a consequence of the currently decreasing grazing pressure on pastures, which has suppressed forest up-growth throughout centuries at high altitude. This kind of habitat reoccupation suggests the tree line in the Central European Alps to behave in a conservative way (Grace et al., 2002). Nevertheless, prognoses of the impact of climate change on the productivity and sustainability of high altitude forest ecosystems will remain uncertain until experimental evidence from long-term field studies on the water and carbon balance in the timberline ecotone will become available.

Finally, one has to be aware that the alpine timberline in the Central European Alps is more susceptible to human impact such as land use changes and management practices than will likely be the case under expected climate change (Wieser and Tausz, 2007). In addition episodic extreme events by e.g. summer drought, severe frost during the growing season or biotic stress (by pathogens/herbivores) rather than the gradual temperature increase will control tree population dynamics within the timberline ecotone of the Central European Alps in the future environment.

Acknowledgements: Part of this research was supported by the Austrian (Federal) grants "Fonds für wissenschaftliche Forschung", Project Nos. P18819-B03 and P19563-B16, "Stem growth and respiration of Pinus cembra at the timberline" and "Cambial activity and wood formation of Scots pine", respectively.

\section{REFERENCES}

Alvarez-Uria P. and Körner Ch., 2007. Low temperature limits of root growth in deciduous and evergreen temperate tree species. Funct. Ecol. 221: 211-218.

Anfodillo T., Rento S., Carraro V., Furlanetto L., Urbinati C., and Carrer M., 1998. Tree water relations and climatic variations at the alpine timberline: seasonal changes of sap flux and xylem water potential in Larix decidua Miller, Picea abies (L.) Karst. and Pinus cembra L. Ann. For. Sci. 55: 159-172.

Aulitzky H., 1963. Grundlagen und Anwendung des vorläufigen Wind-Schnee-Ökogramms. Mitt. Forstl. Bundesversuchsanstalt Mariabrunn 60: 765-834.

Aulitzky H., 1984. The microclimatic conditions in a subalpine forest as basis for the management. Geo Journal 8: 277-281.

Baig M.N. and Tranquillini W., 1980. The effects of wind and temperature on cuticular transpiration of Picea abies and Pinus cembra and their significance in desiccation damage at the alpine treeline. Oecologia 47: $252-256$.
Benecke U., Schulze E.-D., Matyssek R., and Havranek W.M., 1981. Environmental control of $\mathrm{CO}_{2}$-assimilation and leaf conductance in Larix decidua Mill. I. A comparison of contrasting natural environments. Oecologia 50: 54-61.

Beniston M., 2004. The 2003 heat wave in Europe: A shape of things to come? An analysis based on Swiss climatological data and model simulations. Geophys. Res. Lett. 31: 2022-2026.

Beniston M., Diaz H.F., and Bradley R.S., 1997. Climate change at high elevation sites: an overview. Climate Change 36: 233-251.

Beniston M., Keller F., Koffi B., and Goyette S., 2003. Estimates of snow accumulation and volume in the Swiss Alps under changing climatic conditions. Theor. Appl. Climatol. 76: 125-140.

Bergh J. and Linder S., 1999. Effects of soil warming during spring on photosynthetic recovery in boreal Norway spruce stands. Glob. Change Biol. 5: 245-253.

Bianco J. and Dalstein W., 1999. Abscisic acid in needles of Pinus cembra in relation to ozone exposure. Tree Physiol. 19: 787-791.

Breda N., Huc R., Granier A., and Dreyer E., 2006. Temperate forest trees and stands under severe drought: a review of ecophysiological responses, adaptation processes and long-term consequences. Ann. For. Sci. 63: 625-644.

Brunetti M., Maugeri M., Nanni T., Auer I., Böhm R., and Schöner W., 2006. Precipitation variability and changes in the greater Alpine region over the 1800-2003 period. J. Geophys. Res. 111, D11107, DOI: 10.1029/2005JD006674.

Büntgen U., Frank D.C., Schmidhalter M., Neuwirth B., Seifert M., and Esper J., 2006. Growth/climate response shift in a long subalpine spruce chronology. Trees 20: 99-110.

Callaway R.M., 1998. Competition and facilitation on elevation gradients in subalpine forests in the northern Rock Mountains, USA. Oikos 82: 561-573.

Carrer M. and Urbinati C., 2004. Age-dependent tree-ring growth response to climate in Larix decidua and Pinus cembra. Ecology 85: 730-740.

Carrer M. and Urbinati C., 2006. Long-term change in the sensitivity of tree-ring growth to climate forcing in Larix decidua. New Phytol. 170: 861-872.

Cernusca A., 1999. Aims and tasks of ECOMONT. In: Cernusca A., Tappeiner U., and Bayfield N. (Eds.), Land-use changes in European mountain ecosystems. ECOMONT - Concepts and results. Blackwell, Berlin, pp. 13-35.

Christersson L., von Fricks H., and Sihe Y., 1988. Damage to conifer seedlings by summer frost and winter drought. In: Sakai A. and Larcher W. (Eds.), Plant cold hardiness. Alan R Liss, Inc., pp. 203210.

Cornelissen J.H.C., Carnelli A.L., and Callaghan T.V., 1999. Generalities in the growth, allocation and leaf quality responses to elevated $\mathrm{CO}_{2}$ in eight woody species. New Phytol. 141: 401-409.

Crawford R.M.M., 2008. Plants at the margin. Ecological limits and climate change. Cambridge University Press, $478 \mathrm{p}$.

Dalstein L., Torti X., LeThiec D., and Dizengremel P., 2002. Physiological study of declining Pinus cembra (L.) trees in southern France. Trees 16: 299-305.

Däniker A., 1923. Biologische Studien über Baum- und Waldgrenzen, insbesondere über die klimatischen Ursachen und deren Zusammenhänge. Vierteljahresschrift der Naturforschenden Gesellschaft in Zürich 68: 1-102.

Diaz H.F. and Bradley R.S., 1997. Temperature variations during the last century at high elevation sites. Climatic Change 36: 253-279. 
Frank D. and Esper J., 2005. Characterization and climate response patterns of a high-elevation, multi-species tree-ring network in the European Alps. Dendrochronologia 22:107-121.

Friedel H., 1967. Verlauf der alpinen Waldgrenze in Rahmen anliegender Gebirgsgelände. Mitt. Forstl. Bundesversuchsanstalt Mariabrunn 59: $81-172$.

Gehring-Fasel J., Gusian A, and Zimmermann N.E., 2007. Tree line shifts in the Swiss Alps: Climate change or land abandonment. J. Veg. Sci. 18: $571-582$

Gellrich M., Bauer P., Zimmerman N.E., and Koch B., 2007. Agricultural land abandonment and natural forest re-growth in the Swiss mountains. A spatially explicit economic analysis. Agric. Ecosyst. Environ. 118: 93-108.

Goldstein G.H., Brubaker L.B., and Hinckley T.M., 1985. Water relations of white spruce (Picea glauca (Moench) Voss) at tree line in north central Alaska. Can. J. For. Res. 15: 1080-1087.

Grace J. and Rayment M., 2000. Respiration in the balance. Nature 404: 819-820.

Grace J., Berninger F., and Nagy L., 2002. Impact of climate change on the treeline. Ann. Bot. 90: 537-544.

Groisman P.Y., Karl T.R., and Knight R.W., 1994. Observed impact of snow cover on the heat balance and the rise of continental spring temperatures. Science 263: 198-200.

Guggenberger H., 1980. Untersuchungen zum Wasserhaushalt der alpinen Zwergstrauchheide Patscherkofel. Ph.D. thesis, Innsbruck University, $229 \mathrm{p}$.

Gunsch J., 1972. Vergleichende ökologische Untersuchungen von Kleinstandorten im Bereich der subalpinen Zirben-Waldgrenze. Ph.D. thesis, Innsbruck University, 114 p.

Hadley J.L. and Smith W.K., 1989. Wind erosion of leaf surface wax in timberline conifers. Arct. Alp. Res. 21: 392-398.

Hadley J.L. and Smith W.K., 1990. Influence of leaf surface wax and leaf area to water content ratio on cuticular transpiration in western conifers, USA Can. J. For. Res. 20: 1306-1311.

Handa T., Körner Ch, and Hättenschwiler S., 2005. A test of the treeline carbon limitation hypothesis by in situ $\mathrm{CO}_{2}$ enrichment and defoliation. Ecology 86: 1288-1300.

Handa T., Körner Ch., and Hättenschwiler S., 2006. Conifer stem growth at the altitudinal treeline in response to four years of $\mathrm{CO}_{2}$ enrichment. Glob. Change Biol. 12: 2417-2430.

Hantel M., Ehrendorfer M., and Haslinger A., 2000. Climate sensitivity of snow cover duration in Austria. Int. J. Climatol.20: 615-640.

Haselwandter K., 2007. Mycorrhiza in the alpine timberline ecotone: nutritional implications. In: Wieser G. and Tausz M. (Eds.), Trees at their upper limit. Treelife limitation at the alpine timberline. Plant Ecophysiology, vol. 5, Springer, Dorthrecht, The Netherlands, pp. 57-66.

Häsler R., Savi C., and Herzog., 1991. Photiosynthese und stomatäre Leitfähigkeit der Fichte unter dem Einfluß von Witterung und Luftschadstoffen. In: Stark M. (Ed.), Luftschadstoffe und WaldLufthaushalt, Luftverschmutzung und Waldschäden in der Schweiz, vol. 5. Verlag der Fachvereine Zürich, pp. 143-168.

Häsler R., Streule A., and Turner H., 1999. Shoot and root growth of young Larix decidua in contrasting environments near the alpine timberline. Phyton 39: 47-52.

Hättenschwiler S. and Körner Ch., 1995. Responses to recent climate warming of Pinus sylvestris and Pinus cembra within their montane transition zone in the Swiss Alps. J. Veg. Sci. 6: 357-368.
Hättenschwiler S., Miglietta F., Raschi A., and Körner Ch., 1997. Thirty years of in situ tree growth under elevated $\mathrm{CO}_{2}$ : a model for future forest responses? Glob. Change Biol. 3: 463-471.

Hättenschwiler S., Handa I.T., Egli L., Asshoff R., Ammann W., and Körner Ch., 2002. Atmospheric $\mathrm{CO}_{2}$ enrichment of alpine timberline conifers. New Phytol. 156: 365-375.

Havranek W.M., 1972. Über die Bedeutung der Bodentemperatur für die Photosynthese und Transpiration junger Forstpflanzen und für die Stoffproduktion an der Waldgrenze. Angew. Bot. 46: 101-116.

Havranek W.M. and Benecke U., 1978. The influence of soil moisture on water potential, transpiration and photosynthesis of conifer seedlings. Plant Soil 49: 91-103.

Havranek W.M. and Tranquillini W., 1995. Physiological processes during winter dormancy and their ecological significance. In: Smith W.K. and Hinckley T.M. (Eds.), Ecophysiology of coniferous forests. Academic Press, San Diego, pp. 95-124.

Havranek W.M. and Matyssek R., 2005. The carbon balance of European larch (Larix decidua) at the alpine timberline. Phyton 45: 213-231.

Havranek W.M., Wieser G., and Bodner M., 1989. Ozone fumigation of Norway spruce at timberline. Ann. Sci. Forest. 46 Suppl.: 581s-585s.

Havranek W.M., Pfeifhofer H., and Grill D., 1990. Pigmentgehalte und Gaswechsel von Tief- und Hochlagenfichten nach chronischer Ozonbelastung. Forstwiss. Centralbl. 109: 200-209.

Hecke K., Tausz M., Gigel T., HAvranek W.M., Anfodillo T., and Grill D., 2003. Foliar antioxidants and protective pirments in Larix decidua Mill. from contrasting elevations in the Northern and Southern Tyrolean limestone Alps. Forstwiss. Centralbl. 122. 368-375.

Herman F., Smidt S., Huber S., Englisch M., and Knoflacher M., 2001. Evaluation of pollution-related stress factors for forest ecosystems in central Europe. Environ. Sci. Pollut. R. 8: 231-242.

Hoch G. and Körner Ch., 2003. The carbon charging of pines at the climatic treeline: a global comparison. Oecologia 135: 10-21.

Hoch G., Popp M., and Körner Ch., 2002. Altitudinal increase of mobile carbon pools in Pinus cembra suggests sink limitation of growth at the Swiss treeline. Oikos 98: 361-374.

Hoch G., Richter A., and Körner Ch., 2003. Non-structural carbon compounds in temperate forest trees. Plant Cell Environ. 26: 1067-1081.

Holtmeier F.-K., 1973. Geoecological aspects of timberlines in Northern and Central Europe. Arct. Alp. Res. 5: A45-A54.

Holtmeier F.-K-. 1974. Geoökologische Beobachtungen und Studien an der subarktischen und alpinen Waldgrenze in vergleichender Sicht. Steiner, Wiesbaden.

Holtmeier F.-K., 1986. Die obere Waldgrenze unter dem Einfluß von Kilma und Mensch. Abhandlungen aus dem Landesmuseum für Naturkunde 48: 395-412.

Holtmeier F.-K., 2003. Mountain timberlines. Ecology, patchiness, and dynamics. Advances in Global Change Research, vol 14. Kluwer Academic Publishers, Dordrecht, Boston, London, 369 p.

Holtmeier F.-K. and Broll G., 2007. Treeline advance - driving processes and adverse factors. Landscape Online 1: 1-33. DOI:10.33097/LO.200701.

Hurtin K.R. and Marshall J.D., 2000. Altitude trends in conifer leaf morphology and stable carbon isotope composition. Oecologia 123: $32-40$.

IPCC, 2007. Climate change 2007. Cambridge University Press, Cambridge.

Jones P.D., Wigley T.M.L., Folland C.K., Parker D.E., Angelli J.K., Jebedeff S., and Hansen J.E., 1988. Evidence of global warming in the last decade. Nature 332: $791 \mathrm{p}$. 
Kaufmann M.R., 1975. Leaf water stress in Engelmann spruce: Influence of the root and shoot environments. Plant Physiol. 58: 841-844.

Keeling C.D. and Whorf T.P., 2005 Atmospheric $\mathrm{CO}_{2}$ records from sites in the SIO air sampling network (http://cdiac.ornl.guv/trends/co2/ sio-mli.htm).

Keeling C.D., Whorf T.P., Whalen M., and van der Plicht J., 1995. Interannual extremes in the rate of rise of atmospheric carbon dioxide since 1980. Nature 375: 666-670.

Klasner F.L., 2002. A half century of change in alpine patterns at Glacier Nationalpark, Montana, USA Arct. Antarctic Alp. Res. 34. 49-56.

Körner Ch., 1998. A re-assessment of high elevation treeline positions and their explanation. Oecologia 115: 445-459.

Körner Ch., 2003. Carbon limitation in trees. J. Ecol. 94: 4-17.

Körner Ch., 2006. Plant $\mathrm{CO}_{2}$ responses: an issue of definition, time and resource supply. New Phytol. 172:393-411.

Körner Ch., 2007, Climatic treelines: conventions, global patterns, causes. Erdkunde 61: 316-324.

Körner Ch., and Hoch G., 2006. A test of treeline theory on a montane permafrost island. Arct. Antarctic Alp. Res. 38: 113-119.

Körner Ch., Asshoff R., Bignucolo O., Hättenschwiler S., Keel S.G., Pelaez-Riedl S., Pepin S., Siegwolf R.T.W., and Zotz G., 2005. Carbon flux and growth in mature deciduous forest trees exposed to elevated $\mathrm{CO}_{2}$. Science 309: 1360-1362.

Kronfuss H., 1970. Räumliche Korrelation zwischen der Windstärke in Bodennähe und der Schneedeckenandauer. Centralbl. . Gesamt. Forstwes. 87: 99-116.

Kronfuss H. and Havranek W.M. 1999. Effects of elevation and wind on the growth of Pinus cembra L. in a subalpine afforestation. Phyton 39: 99-106.

Kullman L., 2002. Rapid recent range-margin rise of trees and shrub species in the Swedish Scandes. J. Ecol. 90. 68-77.

Larcher W., 1957. Frosttrocknis an der Waldgrenze und in der alpinen Zwergstrauchheide. Veröff. Museum Ferdinandeum, Innsbruck 37: 49-81.

Larcher W., 1963. Zur spätwinterlichen Erschwerung der Wasserbilanz von Holzpflanzen an der Waldgrenze. Ber. Naturwiss. Med. Ver. Innsbruck 53: 125-137.

Larcher W., 1985. Winter stress in high mountains. In: Turner H., Tranquillini W. (Eds.), Establishment and Tending of Subalpine Forests: Research and Management. Ber. Eidgen. Ans. Forstl. Versuchsw. 270, pp. 11-20.

Larcher W., 1994. Ökophysiologie der Pflanzen: Leben, Leistung und Stressbewältigung der Pflanzen in ihrer Umwelt, 5th ed. Ulmer, Stuttgart, $394 \mathrm{p}$.

Larcher W., 2001. Ökophysiologie der Pflanzen. Leben, Leistung und Stressbewältigung der Pflanzen in ihrer Umwelt. 6th ed. UlmerVerlag Stuttgart, $408 \mathrm{p}$.

Leidlmair A., 1983. Landeskunde Österreich. Landesnatur, Kulturlandschaft, Bevölkerung, Wirtschaft, Die Bundesländer. Paul List Verlag, München, 243 p.

Luzian R. and Pindur P., 2007. Prähistorische Lawinen. Nachweis und Analyse holozäner Lawinenereignisse in den Zillertaler Alpen, Österreich. Mitteilungen der Kommission für Quartärforschung der Österreichische Akademie der Wissenschaft Band 16; BFW Berichte Band 141, 247 p.
Matyssek R., Havranek W.M., Wieser G., and Innes J.L., 1997. Ozone and the forests in Austria and Switzerland. In: Sandemann H., Wellburn A.R., and Heath R.L. (Eds.), Forest decline and ozone. A comparison of controlled chamber and field experiments. Ecological Studies, vol. 127. Springer, Berlin, Heildeberg, pp. 95-134.

Matyssek R., Sandermann H., Wieser G., Booker F., Cieslik S., Musselmann R., and Ernst D., 2008a. The challenge of making ozone risk assessment for forest trees more realistic. Environ. Pollut. 156: 567-582.

Matyssek R., Wieser G., Patzner K., Blaschke H., and Häberle K.-H., 2008b. Transpiration of forest trees and stands at different altitude: consistencies rather than contrasts. Eur. J. For. Res. (in press).

Mayr S., Gruber A., and Bauer H., 2003. Repeated freeze-thaw cycles induce embolism in drought stressed conifers (Norway spruce, stone pine). Planta 217: 436-441.

Mayr S., Cochard H., Ameglio T., and Kikuta B., 2007. Embolysm formation during freezing in the wood of Picea abies. Plant Physiol. 143: 60-67.

Menzel A. and Fabian P., 1999. Growing season extend in Europe. Nature 397: 659.

Michealis P., 1934a. Ökologische Studien an der Baumgrenze, IV. Zur Kenntnis des winterlichen Wasserhaushaltes. Jahrb. Wiss. Bot. 80: 169-247.

Michealis P., 1934b. Ökologische Studien an der Baumgrenze, V. Osmotischer Wert und Wassergehalt während des Winters in den verschiedenen Höhenlagen. Jahrb. Wiss. Bot. 80: 337-362.

Mooney H.A. and Winner W.E., 1991 Partitioning response of plants to stress. In: Mooney H.A., Winner W.E., and Pell E.J. (Eds.), Response of Plants to multiple Stresses. Academic Pres, San Diego, CA, pp. 129-141.

Moser M., 1967. Die ektotrophe Ernährungsweise an der Waldgrenze. Mitt. Forstl. Bundesversuchsanstalt Wien 65: 357-375.

Neuner G., 2007. Frost resistance at the upper timberline. In: Wieser G. and Tausz M. (Eds.), Trees at their upper limit. Treelife limitation at the Alpine timberline. Plant Ecophysiology vol. 5. Springer, Dorthrecht, The Netherlands, pp. 171-180.

Neuwinger I., 1970. Böden der subalpinen und alpinen Stufe in den Tiroler Alpen. Mitt.r Ostalpin-Dinarischen Gesellschaft 11: 135150 .

Neuwinger I., 1980. Erwärmung, Wasserrückhalt und Erosionsbereitschaft subalpiner Böden. Mitt. Forstl. Bundesversuchsanstalt Wien 129: 113-144.

Neuwinger-Raschendorfer I., 1961. Bodenfeuchtemessungen. Mitt. der Forstl. Bundesversuchs. Mariabrunn 59: 257-264.

Nicolussi K., Bortenschlager S., and Körner Ch., 1995, Increase in treering width in subalpine Pinus cembra from the central Alps that may be $\mathrm{CO}_{2}$-related. Trees 9: 181-189.

Norby R.S., Wullschleger S.D., Gunderson C.A., Johnson D.W., and Ceulemans R., 1999. Tree response to rising $\mathrm{CO}_{2}$ in field experiments: implications for the forest future. Plant Cell Environ. 22: 683714.

Oberhuber W., 2004. Influence of climate on radial growth of Pinus cembra within the alpine timberline ecotone. Tree Physiol. 24:291-301.

Oberhuber W., 2007. Limitation by growth processes. In: Wieser G. and Tausz M. (Eds.), Trees at their upper limit. Treelife limitation at the Alpine timberline. Plant Ecophysiology vol 5. Springer, Dorthrecht, The Netherlands, pp. 131-143. 
Oberhuber W., KoflerW., Pfeifer K., Seeber A., Gruber A., and Wieser G., 2008. Long-term changes in tree-ring-climate relationships at Mt. Patscherkofel (Tyrol, Austria) since the mid 1980s. Trees 22: 31-40.

Patzelt G., 1996. Modellstudie Ötztal - Landschaftsgeschichte in Hochgebirgsraum. Mitt. Österr. Geogr. Ges. 138: 53-70.

Paulsen J., Weber U.M., and Körner Ch., 2000 Tree growth near treeline: abrupt or gradual reduction with altitude? Arct. Antarctic Alp. Res. 32: $14-20$.

Pfeifer K., Kofler W., and Oberhuber W., 2005. Climate related causes of distinct radial growth reductions in Pinus cembra during the last 200 years. Veg. Hist. Archaeobot. 14: 211-220.

Psenner R. and Nickus U., 1986. Snow chemistry of a glacier in the Central Eastern Alps (Hintereisferner, Tyrol, Austria). Z. Gletscherk. Glaziol. 22: 1-18.

Polle A. and Rennenberg H., 1992. Field studies on Norway spruce trees at high altitudes. II. Defence systems against oxidative stress in needles. New Phytol. 121: 635-642.

Polle A., Havranek W.M., and Wieser G., 1995. Quanitfication of ozone iflux and apoplastic ascorbate content in needles of Norway spruce trees (Picea abies L., Karst) at high altitude. Plant Cell Environ. 18: 681-688.

Polle A., Mössnang M., von Schönborn A., Sladkovic R., and Rennenberg H., 1992. Field studies on Norway spruce trees at high altitudes. I. Mineral, pigment and soluble protein contents of needles as affected by climate and pollution. New Phytol. 121: 89-99.

Richardson A.D., Berlyn G.P., and Gregorie T.G., 2001. Spectral reflectance of Picea rubens (Pinaceae) and Abies balsamifera (Pinaceae) needles along an elevational gradient, Mt. Moosilauke, New Hampshire, USA. Am. J. Bot. 667-676.

Rolland C., Petitcolas V., and Michalet P., 1998. Changes in radial tree growth of Picea abies, Larix decidua, Pinus cembra, and Pinus uncinata near the alpine timberline since 1750. Trees 13: 40-53.

Sakai A. and Larcher W., 1987. Frost survival of plants. Responses and adaptations to freezing stress. Ecological Studies, vol 62. Springer, Berlin, Heidelberg, New York, 321 p.

Saxe H., Ellsworth D.E., and Heath J., 1998. Tree and forest functioning in an enriched $\mathrm{CO}_{2}$ atmosphere. New Phytol. 139: 396-436.

Schär C., Vidale P.L., Lüthi D., Frei C., Häberli C., Mark A., Liniger M.A., and Appenzeller C., 2004. The role of increasing temperature variability in European summer heatwaves. Nature 427: 332-336.

Schwarz R., 1983. Simulationsstudien zur Theorie der oberen Waldgrenze. Erdkunde 37: 1-11.

Shiyatov S.G., Terentev M.M., and Formin V.V., 2005. Spatiotemporal dynamics of forest-tundra communities in the polar urals. Russ. J. Ecol. 36. 69-75.

Slatyer R.O. and Noble I.R., 1992. Dynamics of treelines. In: Hansen A. and DiCastri F. (Eds.), Landscape Boundaries: consequences for biotic Diversity and ecological flows. Ecological Studies, vol. 92. Springer, Berlin, Heidelberg, New York, pp. 346-359.

Smidt S., 1993. Die Ozonkonzentration in alpinen Tälern Österreichs. Centralbl. Ges. Forstwes. 110: 205-220.

Smith W.K., Germino M.J., Hanckock T.E., and Johnson D.M., 2003., Another perspective on altitudinal limits of alpine timberlines. Tree Physiol. 23. 1101-1112.

Sowell J.B., Kouitnik D.L., and Lansing A.J., 1982. Cuticular transpiration of whitebark pine (Pinus albicaulis) within a Sierra Nevadan timberline ecotone, USA. Arct. Alp. Res. 14: 97-103.

Stockwell W.R., Kramm G., Schel H.-E., Mohnen V.A., and Seiler W., 1997. Ozone formation, destruction and exposure in Europe and the
United States. In: Sandermann H., Wellburn A.R., and Heath R.L. (Eds.), Forest decline and ozone: a comparison of controlled chamber and field experiments. Ecological Studies, vol. 127. Springer Verlag, Berlin Heidelberg, pp. 1-38.

Strömgren M. and Linder S., 2002. Effects of nutrition and soil warming on stemwood production in a boreal Norway spruce stand. Glob. Change Biol. 8: 1195-1204.

Szeicz J.M. and MacDonald G.M., 1995. Recent white spruce dynamics at the subarctic alpine treeline of north-western Canada. J. Ecol. 83: $873-885$.

Tausz M., Stabentheiner E., Wonisch A., and Grill D., 1998. Classification of biochemical response patterns for the assessment of environmental stress to Norway spruce. Environ. Sci. Pollut. R 1: 96-100.

Theurillat J.-P. and Gusian A., 2001. Potential impact of climate change on vegetation in the European Alps: a review. Climatic Change 50: $77-109$.

Tranquillini W., 1959a. Die Stoffproduktion der Zirbe (Pinus cembra) an der Waldgrenze während eines Jahres. I. Standortklima und $\mathrm{CO}_{2-}$ Asimilation. Planta 54: 107-129.

Tranquillini W., 1959b. Die Stoffproduktion der Zirbe (Pinus cembra) an der Waldgrenze während eines Jahres. II. Zuwachs und $\mathrm{CO}_{2}$-Bilanz. Planta 54: $130-151$.

Tranquillini W., 1962. Beitrag zur Kausalanalyse des Wettbewerbs ökologisch verschiedener Holzarten. Ber. Deut. Bot. Ges. 75: 356-364.

Tranquillini W., 1973. Der Wasserhaushalt junger Forstpflanzen nach dem versetzen und seine Beeinflussbarkeit. Centralbl. Ges. Forstwes. 90: 46-52.

Tranquillini W., 1976. Water relations at timberline. In: Lange O.L., Kappen L., and Schuklze E.-D. (Eds.), Water relations and plant life. Problems and modern approaches. Ecological Studies, vol 19. Springer Berlin,Heidelberg, New York, pp. 473-491.

Tranquillini W., 1979. Physiological ecology of the alpine timberline. Tree existence at high altitudes with special reference to the European Alps. Ecological Studies, vol 31. Springer, Berlin, Heidelberg, New York, $137 \mathrm{p}$.

Tranquillini W., 1982. Frost drought and its ecological significance. In: Lange O.L., Nobel P.S., Osmond C.B., and Ziegler H. (Eds.), Encyclopaedia of Plant Physiology 12B. Physiological Plant Ecology II. Springer, Berlin, Heidelberg, New York, pp. 379-400.

Turner H., 1968. Über "Schneeschliff" in den Alpen. Wetter und Leben 20: $192-200$.

Turner H., 1993. Alpine microclimates: typology and examples. In: Anfodillo T. and Urbinati C. (Eds.), Ecologia Delle Foreste di alti Quota. Corso di cultura in ecologia 30. University Padua, pp. 27-34.

Turner H. and Streule A., 1983. Wurzelwachstum und Sprossentwicklung junger Koniferen im Klimastress der alpinen Waldgrenze, mit Berücksichtigung von Mikroklima, Photosynthese und Stoffproduktion. Wurzelökologie und ihre Nutzanwendung. Internationales Symposium Gumpenstein, 1982. Bundesanstalt Gumpenstein, pp. 617-635.

Turner H., Rochat P., and Streule A., 1975. Thermische Charakteristik von Hochlagenstandorten im Bereich der oberen Waldgrenze (Stillberg, Dischmatal bei Davos). Mitt. Eidgen. Anst. Forstl. Versuchswesen Birmensdorf 51: 95-119.

Volgger E., 1995. Zur Ozonempfindlichkeit der europäischen Lärche (Larix decidua Mill.) an der Waldgrenze. Diploma thesis, Innsbruck University, $112 \mathrm{p}$.

Vollenweider P., Ottiger M., and Günthardt-Goerg M.S., 2003. Validation of leaf ozone symptoms in natural vegetation using microscopical methods. Environ. Pollut. 124: 101-118. 
Walther G.-R., 2003. Plants in a warmer world. Perspect. Plant Ecol. Evol. Syst. 6: 169-185.

Walther G.-R., Beißner S., and Pott R., 2005. Climate change and high mountain vegetation shifts. In: Broll G. and Keplin B. (Eds.). Mountain ecosystems. Studies in Treeline Ecology. Springer, Berlin, Heidelberg, pp. 77-95.

Wan X., Landhäusser S.M., Zwiazek J.J., and Lieffers J.L. 1999. Root water flow and growth of aspen (Populus tremuloides) at low root temperatures. Tree Physiol. 19: 897-387.

Wardle P., 1974. Alpine timberlines. In: Ives J.D. and Barry R. (Eds.), Arctic and Alpine Environments. Methuen Publishing, London, pp. 371-402.

Wieser G., 1997. Carbon dioxide gas exchange of cembran pine (Pinus cembra) at the alpine timberline during winter. Tree Physiol. 17: $473-477$.

Wieser G., 2004. Seasonal variation of soil respiration in a Pinus cembra forest at the upper timberline in the Central Austrian Alps. Tree Physiol. 24. 475-480.

Wieser G. and Bahn M., 2004. Seasonal and spatial variation in woodytissue respiration in a Pinus cembra tree at the alpine timberline in the Central Austrian Alps. Trees 18: 576-580.

Wieser G. and Havranek W.M., 2001. Effects of ozone on conifers in the timberline ecotone. In: Huttunen S., Heikkilä H., Bucher J., Sundberg B., Jarvis P., and Matyssek R. (Eds.), Trends in European forest tree physiology research. Tree Physiology, vol 2. Kluwer Academic Publishers, Dorthrecht, Boston, London, pp. 115-125.

Wieser G. and Stöhr D., 2005. Net ecosystem carbon dioxide exchange dynamics in a Pinus cembra forest at the upper timberline in the central Austrian Alps. Phyton 45: 233-242.
Wieser G. and Tausz M., 2007. Trees at their Upper Limit: Treelife limitation at the alpine timberline. Plant Ecophysiology, vol. 5. Springer, $232 \mathrm{p}$.

Wieser G., Gigele T., and Pausch H., 2005. The carbon budget of an adult Pinus cembra tree at the alpine timberline in the Central Austrian Alps. E. J. For. Res. 124: 1-8.

Wieser G., Häsler R., Götz B., Koch W., and Havranek W.M., 2000. Role, of climate, crown position, tree age and altitude in calculated ozone flux into needles of Picea abies and Pinus cembra: s synthesis. Environ. Pollut. 109: 415-422.

Wieser G., Manning W.J., Tausz M., and Bytnerowicz A., 2006. Evidence for potential impacts of ozone on Pinus cembra L. at mountain sites in Europe: An overview. Environ. Pollut. 139: 53-58.

Wieser G., Tausz M., Wonisch A., and Havrabnek W.M., 2001. Free radical scavangers and photosynthetic pigments in Pinus cembra L. needles as affected by ozone exposure. Biol. Plant. 44: 225-232.

Wilmking M., Juday G.P., Barber V.A., and Zald H.S.J., 2004. Recent climate warming forces contrasting growth responses of white spruce at treeline in Alaska through temperature thresholds. Glob. Change Biol. 10: 1724-1736.

Zha T., Kellomaki S., Wang K.Y., and Rouvien I., 2004. Carbon sequestration in for 4 years in a Scots pine forest. Glob. Change Biol. 10: $1492-1503$

Zwerger P. and Pindur P., 2007. Waldverbreitung und Waldentwicklung im Oberen Zemmgrund. In: Luzian R. and Pindur P. (Eds.), Prähistorische Lawinen. Nachweis und Analyse holozäner Lawinenereignisse in den Zillertaler Alpen, Österreich. Mitteilungen der Kommission für Quartärforschung der Österreichische Akademie der Wissenschaft Band 16; BFW Berichte Band 141, pp. 69-97. 